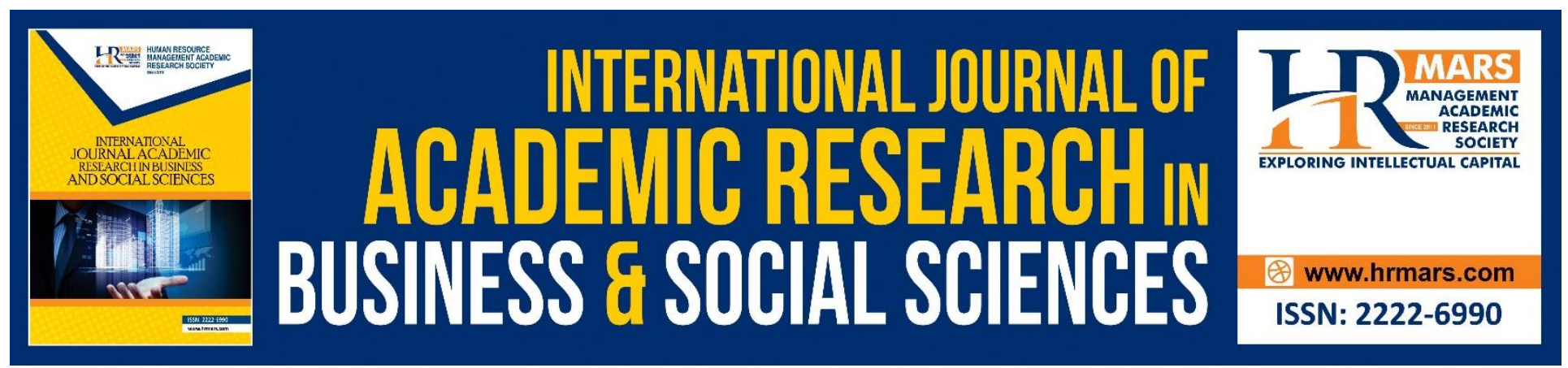

\title{
The Role of Bank Credit in Kuwait Economic Growth
}

\author{
Ibrahim Arslan, Yusuf Bozgeyik, Zaid Al-Azaki
}

To Link this Article: http://dx.doi.org/10.6007/IJARBSS/v9-i2/5607

DOI: $\quad 10.6007 /$ IJARBSS/v9-i2/5607

Received: 02 Feb 2019, Revised: 21 Feb 2019, Accepted: 06 March 2019

Published Online: 08 March 2019

In-Text Citation: (Arslan, Bozgeyik, \& Al-Azaki, 2019)

To Cite this Article: Arslan, I., Bozgeyik, Y., \& Al-Azaki, Z. (2019). The Role of Bank Credit in Kuwait Economic Growth. International Journal of Academic Research in Business and Social Sciences, 9(2), 686-700.

\section{Copyright: (C) 2019 The Author(s)}

Published by Human Resource Management Academic Research Society (www.hrmars.com)

This article is published under the Creative Commons Attribution (CC BY 4.0) license. Anyone may reproduce, distribute, translate and create derivative works of this article (for both commercial and non-commercial purposes), subject to full attribution to the original publication and authors. The full terms of this license may be seen at: http://creativecommons.org/licences/by/4.0/legalcode

Vol. 9, No. 2, 2019, Pg. 686 - 700

Full Terms \& Conditions of access and use can be found at http://hrmars.com/index.php/pages/detail/publication-ethics 


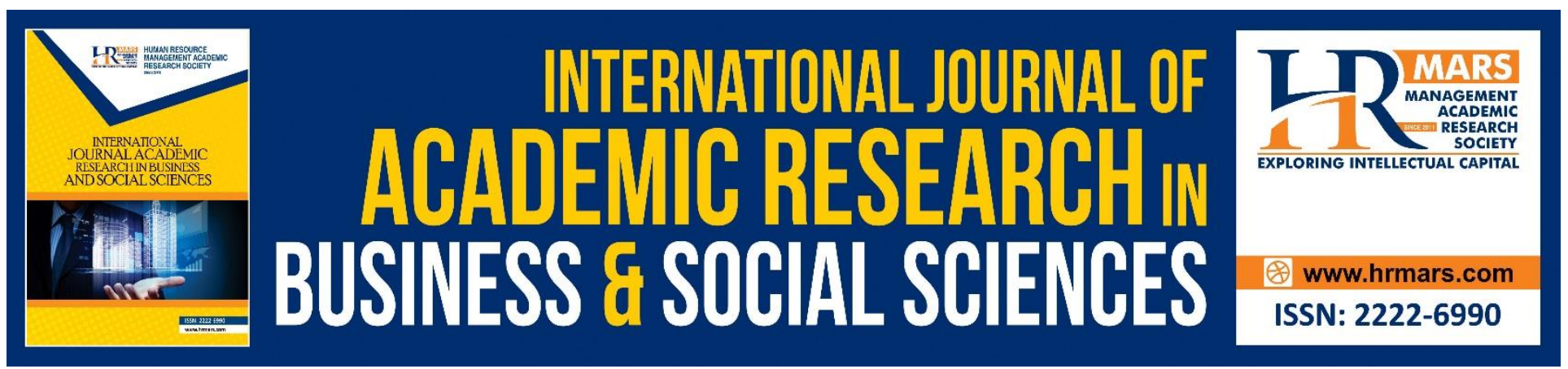

\title{
The Role of Bank Credit in Kuwait Economic Growth
}

\author{
Ibrahim Arslan \\ Professor, Faculty of Administration and Economic, Department of Economics, Gaziantep \\ University. \\ Yusuf Bozgeyik
}

Assoc. Professor, Faculty of Administration and Economics, Department of Finance,Gaziantep

University.

Zaid Al-Azaki

PhD Scholar, Social Sciences institute, Depatment of Economics,Gaziantep University. E-

mail:zaid.alazaki@gmail.com .

\section{Abstract}

The aim of this study is to know the role of bank credit in Kuwait's economic growth in a number of sectors through quarterly data for the period 2000 - 2017, through standard analysis method using a number of tests such as "Unit root tests", "Johansen cointegration test", " Granger Causality Test " and the "Vector Error Correction Model".

The results of the long term estimation were showing clearly that the non oil gross domestic (GDP) is positively correlated with Total Banking Credit (TBC), Bank Credit granted to Construction and Real estate sectors (BCCR), Bank Credit granted to Industry sector $(\mathrm{BCl})$ and Bank Credit granted to Trade sector (BCT), it shows also the small relationship between the study variables in short-run.

Granger causality result shows the causal relationship for one direction from non oil gross domestic product to Bank credit granted to Industry sector, and also construction and real estate sector. As well the results explained the existence of bidirectional causality between bank credit at construction real estate sector and Bank Credit for trade sector. During this study we observed bidirectional causality among Total Bank Credit and bank credit to Industry and between bank credit at trade sector to bank credit at construction real estate sector. Whereas the real estate sector and industry sectors are one of the most important sectors in the Kuwait economy.

In this study we found out that the bank credits in a basic economic sectors has not prominent role in the growth of the Kuwaiti economy, so the need arises to improve role of Banking sector inorder to enhance economics through the Central Bank of Kuwait by liberalize financial restrictions and encourage banks to expand the granting of credit to the economic sectors, which will leading to promote economic growth. 
INTERNATIONAL JOURNAL OF ACADEMIC RESEARCH IN BUSINESS AND SOCIAL SCIENCES

Vol. 9, No. 2, Feb, 2019, E-ISSN: 2222-6990 @ 2019 HRMARS

Keywords: Bank Credit, Economic Growth, Cointegration, Granger Test

\section{Introduction}

Economic growth is considered a major objective of economic policies in many countries, Where it is considered one of the most important parameters of economic policies in developing countries. The increase in GDP leads to an increase in average real per capita income, This concept is consistent with the World Bank's definition of economic growth, which it defines as "an increase in real output with an increase in average per capita income"(The World Bank, 2012).

To achiev economic growth in any country is not that easy way, as there are basic requirements and preconditions that must be met to achieve it in the form and rate required. Among the most important elements may be the availability of adequate financial resources from suitable sources of investment financing to achieve the increase in income and production, so the banking system is the cornerstone of economic development in any country, which is undoubtedly a priority currency providing credit to different economic sectors in a manner that contributes to the process of economical development. Where the ability of banking sector to finance economic development through the financing of investment projects by granting credit facilities, which according to Schumpeter opinion in the writing of the theory of economic development contribute to the process of capital formation. A new purchasing power reflected in the end means to produce a new reality and purchasing power is necessary to finance the process of economic development and growth (Alsayed Ali , 1984).

Many economists in their studies, such as McKinon and Shaw (1973), emphasized the significant role of fiscal policy in stimulating economic activity, in which any lack of funding has negative effects on the production process and the use of available resources, and represents an obstacle to economic activity, as that imposition of restrictions by the governments of developing countries on banking leads to the weakening in the role of financial intermediaries, to the reduction of savings and investment, and obviously to the deterioration of economic growth, for this reason, fiscal liberalization has been proposed as an alternative to stimulating savings in order to increase the feeding of loans to private sector, that leading to increase investment and high growth ratio of economic activity (Al Qadeer, 2005).

The banking system are the spine of the economy, so the banking sector must play the pivotal role in securing greater support for the economy in the process of enhancing its traditional growth sources, seeking new sources of growth and expanding its funding for all economic sectors. The banking sector is considered one of the most important economic sectors and the most sensitive and influential in the growth of the economies of countries. As this sector occupies a vital position in economic and financial systems because of its positive impact on economic development, by mobilizing sufficient savings required by economic growth and efficient distribution in different areas of investment. The role of the banking sector is not limited to being a link between borrowers and savers, its leads to a prominent role in regulating the flow of funds from savers and redistributing them through investment channels to ensure the optimal use of these funds.

Kuwait's economy has been hit by a severe financial crisis since mid-2014 due to the drop in oil prices, Whereas Kuwait is one of the most prominent and rich oil-exporting countries, which depends on it mainly where the ratio of oil revenues between $50 \%$ and $60 \%$ of GDP ,As a result of the collapse 
of oil prices, the GDP was affected by the decline. If this decline continues, this will lead to economic collapse due to its dependence on oil revenues. So to maintain sustainable economic development in this country, they have to reconsider and look for other revenues sources than oil revenues, through investments in all sectors and financing these investments through bank credit ( alhabib, 2000).

Due to importance of the banking sector, it became necessary to identify the essence of its activity which is the granting of bank credit and its development and its contribution to economic growth. The number of banks operating in Kuwait are 23 banks in addition to financial robustness, especially in terms of liquidity, profitability and solvency ratios.

The lending to deposits ratio stands at $85 \%$, an indication of the importance of banks for supporting the various economic fields benefiting from financing. In view of the trend towards oil production and future oil shortages, which may affect Kuwait's economic growth, and the fact that bank credit is important in increasing economic growth through increased investment and productivity, the problem of this study is about the role of Bank credit granted in economic growth represented by GDP.

The importance of this study comes through the important functions of banks in economic development at the level of the economy as a whole and at the level of various economic sectors, it also highlights the importance of the study to know which economic sectors have a major contribution to the GDP in Kuwait, and therefore to know whether there is a need to adjust the policy of the banking sector in directing banking investments towards the economic sectors.

This study is intended to determine the role of bank credit provided to the Kuwaiti economic activity during the period 2000-2018 based on quarterly data and the application of time series analysis method.

\section{Literature Review}

Several studies have dealt with about impact of bank credit on the economic activity of many countries and on the basis of various statistical and standard methods. Thus studies and experiences in most countries of the world have proved the importance of the financial and banking system in economic growth, since the first study by Schmpeter (1911) on the relationship between the financial development and economical development. Which it was concluded that financial development is crucial for economic development. Through the functions of Banking institutions, technical innovation and Growth of the economy are stimulated by financing Productive projects. As Schumpeter points out in his stady that the banking system is the supporting factor for economic growth due to its role in attract savings and the funding of productive projects.

From the beginning of 1900, The focus was on economic growth where scientists for economic growth right by offering various opinions and ideas about growth of the economy contributed in the development of the theory.

John and kimberly (2015), find out the impact of credit on investment during the 2008 financial crisis, that bank credit provides liquidity insurance, which helps companies to maintain their investments that enhance value when liquidity is limited under harsh economic times. 
Copelman (2000), investigate the effect of the expansion of banking credit on the economic growth in Mexico, using the linear regression methodology (AVR), he found out an increase in bank credit, which leads to a significant increase in production, economic growth.

Suna Korkmaz (2015) aimed to find out whether the local credit granted by the banking sector affected by macroeconomic variables such as inflation and growth of the economy of ten European countries, through the analysis of the data 2006-2012, the study showed the local credit granted by the banking sector does not affect Inflation, but affected economic growth.

Arslan and Yaprakl (2008), Investigate the correlation between bank loans and inflation in Turkey, depending on data for total bank credit and inflation for the period 1983-2007, using Johansen co-integration analysis and error correction model, the relationship between bank credit and inflation was analyzed. The results found that the bank credit is negatively affected by inflation, While the positive effect of bank credit on inflation in the long run. Moreover, error correctionaugmented Granger causality tests show that bidirectional causality exists between bank credit and inflation.

That high inflation and interest rates lead to a drop in demand for bank deposits, which limits banks to credit resources and thus leads to a reduction in spending (Kamin and Roger, 2000). When pursuing an effective banking and monetary policy, credit grants have a direct impact on spending and thus reflected on prices and curb inflation.

In this context, for change the relation between the banking sector and inflation in a positive way, it is necessary to strengthen the banking system by reducing inflation through an effective monetary policy and to establish a new economic environment with a disciplined fiscal policy, otherwise, the inflation problem hinders the expansion of an effective economic structure and the growth of the banking sector and hinders the realization of productive investments by affecting bank loans.

Emmanuel, et al., (2015), empirically investigated to study the effect of private credit on Nigerian economic growth, covering 2000-2014 period, by Gregory and co-integration test, the results showed the error correction model confirmed there is a statistically positive impact of banking loans on output, while increased bank credit inhibiting growth rate. Also, the obligation of the central bank to the piecemeal reduction in interest rates was had a prominent role in achieving economic growth.

Al-Ameri (2003), study the effect of bank loans on economic growth, during the period 19902001. The method of the lower squares was applied through a standard linear model to measure the factors affecting credit. The study showed a limited positive impact of credit on economic growth.

ÇEÇE (2012), examined the direct relation between bank credits and turkey's economic growth, it's conducted with quarterly data of GDP, bank credits. The study used unit root tests, VAR analysis, vector error correction model, cointegration analysis and Granger test. The empirical results shows unidirectional causal relation from credits to economic growth.

ERTAY (2014), estimated the relevance between banking sector and turkish economic growth. Granger test, Cointegration model was applied, the study was carried out in the light of GDP in Turkey between the years 2003Q1- 2013Q4 and bank loans taken on quarterly periods. The empirical results showed that the banking system played active role in determining economic growth and the banking sector can be used as a means of economic growth. 
Tongurai (2017), examined the effect of banking strip evolution on changes in the economic structure, and whether the economic structure and growth promote the development of the banking sector, of all countries of the world during the period 1960 - 2016. They found that the evolution of banking strip has a negative effect on expansion of the agricultural strip and has no effect on the evolution of the industrial sector, and this negative impact is only for countries with high levels of development of the banking sector. It also showed that the evolution of agricultural strip has a negative effect on the evolution of banking sector, while the evolution of the industrial sector has a positive effect on the evolution of the banking sector.

Belinga, et al.,( 2016 ), investigates the relation between bank credit and economic growth in Cameroon through bank credit granted to the private sector as well as deposits, and economic growth expressed in GDP Per Capita, depending for the period 1969-2014. Several standard statistical tests have been used as a stationarity test (ADF), Johansen Cointegration test, (VECM). Where results showed that there is a one-way causal relationship from credit facilities granted to the private sector and bank deposits GDP Per Capital, these results reflect the success of monetary policy in Cameroon and its support for economic growth.

Caporale, et al., ( 2009), reviewed study the characteristics of the financial and banking strip in 10 countries of the European Union, discussed the relevance between financial evolution and economic growth over the period 1994-2007. The results show the stock market and credit are inefficient, and their effect is limited on economic growth. on other hand, Granger result suggest that causality of one direction from financial development to economic growth.

Alkhazaleh (2017), his study was aimed to know the the extent to which commercial banking services contribute to economic growth in Jordan, he focused on analyzing the relationship between variables, in which independent variables are represented profitability, loans and deposit were studied as an indicator for performance of banks, the dependent variable is represented by the GDP as an indicator for economic growth. They covered the annual data of 13 banks for 2010-2015. Using OLS, The results showed a relationship between banking performance and economic growth.

Burzynska (2009), empirically investigated to define the effect of bank sector on economic growth and the appropriateness of fiscal politics with efficient economy, using data for time series 1978-2005. Granger test and VAR were applied to study relationship between study variables (economic growth, different types of banks and different types of loans). The results showed oneway causality is affected by the type of bank and type of loan. Also the results explained the existence of bidirectional causality between economic growth and policy banks. further, loans granted to construction sector influence economic growth.

Alfari (2012), investigated the role of the banking strip in financing economic expansion in Palestine during time series 1995-2011, aimed to identifyd the importance of the Palestinian banking sector and how it contribute in the Palestinian economy, identify factors affecting the volume of banking credit as one of the main financing resource in the bank, measure the impact of the size of the credit from the banking sector in the Palestinian economy. The study found out the relationship between the banking loans and the GDP that each affects the other.

Christopher (2016), examined the effect of financial intermediation and growth of the Nigerian economy. Covering annual data for the period 1970-2013 were using analyze the long and short runs relationships between development financial and economic growth along with the direction of 
causality between the indicators. The results found fixed long run relationship between economic growth and indicators of financial intermediation. The causality result reveals a bidirectional relation between economic growth and inflation while a unidirectional causality between financial savings and economic growth.

\section{Data and Methodology}

\section{Data}

Based study is on quarterly data spans the period 2000Q1 - 2017Q4, on following study variables: non Oil (GDP), Total bank credit granted (TBC), credit granted to Trade sector (BCT), credit granted to Industry sector $(\mathrm{BCl})$, credit granted to Construction and Real Estate sector (BCCR). The data taken from Central Bank of Kuwait (CBK).

\section{Methodology}

Based on the objective of the study to investigate the role of bank credit granted in the Kuwait economic growth, we specify a standard model based on multiple regression which includes a dependent variable and five independent variables, which has been identified as follows:

$$
\mathrm{GDP}=\mathrm{F}(\mathrm{TBC}, \mathrm{BCT}, \mathrm{BCl}, \mathrm{BCCR})
$$

TO convert the function into a linear formula, it takes the following form:

$$
\mathrm{GDP}=\beta_{0}+\beta_{1} \mathrm{TBC}+\beta_{2} \mathrm{BCT}+\beta_{3} \mathrm{BCl}+\beta_{4} \mathrm{BCCR}+\varepsilon \mathrm{i}
$$

Where:

GDP: Non Oil Gross Domestic, which is the measure of economic growth

TBC: Total Bank Credit granted

$\mathrm{BCl}$ : Credit granted to Industry sector

BCT: Credit granted to Trade sector

BCCR: Credit granted to Construction and Real Estate sector

घi: is an error term. $\quad \beta_{0}, \beta_{1}, \beta_{2}, \beta_{3}, \beta_{4}$ : The model parameters.

For econometric analysis, the functional equation will be transformed into a linear function:

$$
\operatorname{LnGDP}=\beta_{0}+\beta_{1} \operatorname{LnTBC}+\beta_{2} \operatorname{LnBCT}+\beta_{3} \operatorname{LnBCl}+\beta_{4} \operatorname{LnBCCR}+\varepsilon i
$$

\section{Unit Root Test}

To know the degree of cointegration for variables, the root of unit is tested for each variable individually. Panel root tests have been developed in order to examine stability of panel series. The tests are based on Dickey Fuller(1979) and Extended Dickey Fuller (ADF) testing approaches for the establishment of hypotheses and calculation of test statistics.

Most commonly unit root tests we used are the Augmented Dickey-Fuller, and Phillips-Perron (PP) unit root test , according to the following equation: (Damondar, 2004)

$$
\Delta \mathrm{Yt}=\beta 1+\beta 2 \mathrm{t}+\delta \mathrm{Yt}-1+\sum_{i=1}^{m} \alpha \mathrm{i}
$$

Where is : $\Delta=$ first difference operator,$\Delta Y \mathrm{t}-1=(\mathrm{Yt}-1-\mathrm{Yt}-2)$, Yt The variable to be test the stability of its time series, $\mathrm{t}=$ time trend, $\varepsilon \mathrm{t}=$ error trem

\section{Cointegration Test}


The cointegration test measures the equilibrium relationship between variables in the long term, in which the tested variables must be unstable in their level and have the same degree of stability. The cointegration test was applied to determin the degree of cointegration for the variables of this study. This test assumes a single integrated vector binds all the variables together (Abdul Razzaq, et al., 2012).

The most common test in this regard is the (Johansen, 1988-1991) maximum likelihood test is employed to examine the cointegration between the variables, to determine the number of cointegration vectors, these two tests are proposed: (Johansen and Juselius, 1990).

\section{Tract Test}

A hypothesis is tested that there are at most $q$ of the shared integration vectors versus the unrestricted model general form $(r=q)$, This test is calculated according to formula (Buiguta, 2012).

$$
\lambda \text { Trace }(r)=-T \sum_{i=r+1}^{q} \ln (1-\lambda i)
$$

Where: T sample size, $r$ number of vectors cointegration. The null hypothesis is based on a number of Vector Cointegration is equal to the most $r$, where $(r=0,1)$ according to the estimated function.

\section{Maximum Eigen Test}

Maximum Eigen test was calculated according the formula: (Brooks, 2008)

$$
\lambda \operatorname{Max}(r, r+1)=-T \ln (1-\lambda r+1) \ldots . .(6)
$$

where $\lambda r$ smallest estimated Eigen values

\section{Granger Causality Test}

This study is based on the Granger test at to spot the direction of the causative relation between variables. According to the Granger concept the Yt variable causes Xt. This test is mainly based on the (F) test. This hypothesis is examined by comparing the absolute calculated value for (F) with the critical scale value at a confirmed level of significance. The null hypothesis is unacceptable if calculated $\mathrm{F}$ is more than that of table (absolute value), whic indicating that there is an influence relationship between the variables.

\section{Empirical Results}

Tests were conducted on the stability of time series, natural distribution, Co-integration test, VECM and Granger test. The results of these tests are as follows :

\section{Tests for Unit Root}

The results of unit root test conducted on the included variables are offered in (Table 1). We used (ADF), and (PP) tests. The results of these tests indicate that the time series of the study variables are unstable at the (level), but stabilized when taking the first differences at $5 \%$ level of significance.

\section{Table 1: Unit Root results}

\begin{tabular}{|c|c|c|}
\hline Variable & ADF & PP \\
\hline
\end{tabular}


INTERNATIONAL JOURNAL OF ACADEMIC RESEARCH IN BUSINESS AND SOCIAL SCIENCES Vol. 9, No. 2, Feb, 2019, E-ISSN: 222 2-6990 @ 2019 HRMARS

\begin{tabular}{|c|c|c|c|c|c|c|c|c|c|}
\hline & \multicolumn{2}{|c|}{ LEVE } & \multicolumn{2}{|c|}{ 1st Difference } & \multicolumn{2}{|c|}{ LEVE } & \multicolumn{2}{|c|}{ 1st Difference } \\
\hline & & $\begin{array}{c}\mathrm{t}- \\
\text { Statistic }\end{array}$ & Prob. & $\begin{array}{c}\mathrm{t}- \\
\text { Statistic }\end{array}$ & Prob. & $\begin{array}{c}\mathrm{t}- \\
\text { Statistic }\end{array}$ & Prob. & $\begin{array}{c}\mathrm{t}- \\
\text { Statistic }\end{array}$ & Prob. \\
\hline \multirow[b]{2}{*}{ GDP } & Constant & -5.93 & 0.8684 & -3.2475 & 0.0213 & -0.0798 & 0.947 & -3.272 & 0.0021 \\
\hline & $\begin{array}{l}\text { Constant } \\
\& \text { trend }\end{array}$ & -2.4345 & 0.3591 & -3.2148 & 0.0427 & -1.8108 & 0.6891 & -3.2131 & 0.0045 \\
\hline \multirow[b]{2}{*}{ TBC } & Constant & -1.0665 & 0.7244 & -2.4872 & 0.0459 & -0.2236 & 0.928 & -3.597 & 0.0082 \\
\hline & $\begin{array}{c}\text { Constant } \\
\& \text { trend }\end{array}$ & -2.0456 & 0.5662 & -2.4059 & 0.0543 & -1.8948 & 0.6468 & -3.5006 & 0.0371 \\
\hline \multirow[b]{2}{*}{$\mathrm{BCl}$} & Constant & -1.0645 & 0.7254 & -8.4088 & 0.0000 & -1.0619 & 0.7267 & -8.4088 & 0.0000 \\
\hline & $\begin{array}{c}\text { Constant } \\
\& \text { trend }\end{array}$ & -3.1644 & 0.9884 & -6.7319 & 0.0000 & -1.0569 & 0.9286 & -8.3562 & 0.0000 \\
\hline \multirow[b]{2}{*}{$\mathrm{BCT}$} & Constant & 0.1156 & 0.9648 & -9.5164 & 0.0000 & 0.4434 & 0.9835 & -9.9450 & 0.0001 \\
\hline & $\begin{array}{c}\text { Constant } \\
\& \text { trend }\end{array}$ & -4.0751 & 0.0105 & -9.5069 & 0.0000 & -4.0751 & 0.0105 & -10.007 & 0.0000 \\
\hline \multirow{2}{*}{$\begin{array}{c}\mathrm{BCC} \\
\mathrm{R}\end{array}$} & Constant & -0.8837 & 0.7879 & -2.0057 & 0.0283 & -0.8163 & 0.8082 & -7.0520 & 0.0000 \\
\hline & $\begin{array}{l}\text { Constant } \\
\& \text { trend }\end{array}$ & -3.1644 & 0.9884 & -2.2262 & 0.0410 & -1.0569 & 0.9286 & -7.0580 & 0.0000 \\
\hline
\end{tabular}

Source: Computed by using E-views 8.

\section{Cointegration Results}

Applying the Johansen's methodology for co-integration, for Tract test, and the Maximum Eigen test on Study variables, Based on the results of cointegration in Table 2, When testing the null hypothesis versus the alternative hypothesis, it was found that the calculated value (Tract-Statistic) at significant level of $1 \%$ are greater than the tabular value (Critical-Value). As for the Maximum Eigen Test, the value of (Max Egin-Statistic) calculated are greater than the tabular value (Critical-Value) at a significant level of $1 \%$.

Table 2: Johansen Cointegration tests

\begin{tabular}{|c|c|c|c|c|}
\hline \multicolumn{5}{|c|}{ Trace Test } \\
\hline $\begin{array}{c}\text { Hypothesized No. } \\
\text { of CE(s) }\end{array}$ & Eigen Value & Trace Statistic & $\begin{array}{c}\text { Critical Value } \\
\mathbf{5 \%}\end{array}$ & Prob.** \\
\hline None ${ }^{*}$ & 0.511108 & 102.8697 & 69.81889 & 0.0000 \\
\hline
\end{tabular}


INTERNATIONAL JOURNAL OF ACADEMIC RESEARCH IN BUSINESS AND SOCIAL SCIENCES Vol. 9, No. 2, Feb, 2019, E-ISSN: 2222-6990 C 2019 HRMARS

\begin{tabular}{|c|c|c|c|c|}
\hline At most 1 * & 0.295253 & 53.49229 & 47.85613 & 0.0135 \\
\hline At most 2 & 0.211152 & 29.34807 & 29.79707 & 0.0563 \\
\hline At most 3 & 0.169814 & 12.98253 & 15.49471 & 0.1155 \\
\hline At most 4 & 0.002045 & 0.141243 & 3.841466 & 0.7070 \\
\hline Trace test indicates 2 cointegratingeqn(s) at the 0.05 level \\
\hline \multicolumn{5}{|c|}{ Maximum Eigenvalue } \\
\hline $\begin{array}{c}\text { Hypothesized No. } \\
\text { of CE(s) }\end{array}$ & Eigen Value & Trace Statistic & $\begin{array}{c}\text { Critical Value } \\
5 \%\end{array}$ & Prob.** \\
\hline None * & 0.511108 & 49.37740 & 33.87687 & 0.0004 \\
\hline At most 1 & 0.295253 & 24.14422 & 27.58434 & 0.1298 \\
\hline At most 2 & 0.211152 & 16.36555 & 21.13162 & 0.2042 \\
\hline At most 3 & 0.169814 & 12.98253 & 14.26460 & 0.0829 \\
\hline At most 4 & 0.002045 & 0.141243 & 3.841466 & 0.7070 \\
\hline Max-eigenvalue test indicates 1 cointegratingeqn(s) at the 0.05 level \\
\hline
\end{tabular}

Source: Computed by using E-views 8.

So, the null hypothesis is not accepted and the alternative hypothesis is accepted that indicates one co-integrating vector at least, and the long run relationship deduced between Non Oil GDP and (TBC, BCl, BCT, BCCR).

\section{The Results of Granger Causality Tests}

Granger causality Test was conducted and according to analyzing the cointegrating, it indicates present one cointegrating vector at least, and the a long run relation between dependent variable and independent variables.

Table 4: Granger Causality Tests

\begin{tabular}{|c|c|c|}
\hline Null Hypothesis: & F-Statistic & Prob. \\
\hline BCCR Non Cause GDP & 0.26519 & 0.7679 \\
\hline
\end{tabular}


INTERNATIONAL JOURNAL OF ACADEMIC RESEARCH IN BUSINESS AND SOCIAL SCIENCES Vol. 9, No. 2, Feb, 2019, E-ISSN: 2222-6990 C 2019 HRMARS

\begin{tabular}{|l|l|l|}
\hline GDP Non Cause BCCR & 6.77566 & 0.0021 \\
\hline BCT Non Cause BCCR & 9.73866 & 0.0002 \\
\hline BCCR Non Cause BCT & 4.02506 & 0.0225 \\
\hline BCCR Non Cause BCI & 5.40600 & 0.0067 \\
\hline BCI Non Cause BCCR & 1.57999 & 0.2138 \\
\hline TBC Non Cause BCCR & 8.54069 & 0.0005 \\
\hline BCCR Non Cause TBC & 1.86698 & 0.1628 \\
\hline BCT Non Cause BCI & 8.17818 & 0.0007 \\
\hline BCI Non Cause BCT & 0.29028 & 0.7490 \\
\hline GDP Non Cause BCI & 2.85644 & 0.0647 \\
\hline BCI Non Cause GDP & 0.03320 & 0.9674 \\
\hline TBC Non Cause BCI & 5.75143 & 0.0050 \\
\hline BCI Non Cause TBC & 5.51976 & 0.0061 \\
\hline GDP Non Cause BCT & 12.5211 & $3 . \mathrm{E}-05$ \\
\hline BCT Non Cause GDP & 0.74317 & 0.4796 \\
\hline TBC Non Cause BCT & 12.9768 & $2 . \mathrm{E}-05$ \\
\hline BCT Non Cause TBC & 1.49717 & 0.2314 \\
\hline TBC Non Cause GDP & 0.20972 & 0.8114 \\
\hline GDP Non Cause TBC & 14.9275 & $5 . \mathrm{E}-06$ \\
\hline
\end{tabular}

Source: Computed by using E-views 8.

The results of the Granger test showed a positive one-way causality from $\mathrm{BCCR}$ to $\mathrm{BCl}$, from GDP to $B C C R$, from $T B C$ to $B C C R$, from $B C T$ to $B C l$, from GDP to $B C l$. Also, the bidirectional causality observed among variables $\mathrm{BCT}, \mathrm{BCCR}$, and $\mathrm{TBC}, \mathrm{BCl}$.

\section{The Results of Vector Error Correction Model}

Based on the results of the cointegration test and the Granger causality test, resulted in a longrun equilibrium relationship between the variables of this study. The relationship was estimated in the short term using the VECM model. In conducting the test, the results shown in the table 5 were reached.

Table 5: Vector Error Correction Tests

Dependent Variable: D(GDP)

Method: Least Squares (Gauss-Newton / Marquardt steps)

Date: 01/13/19 Time: 17:27 
INTERNATIONAL JOURNAL OF ACADEMIC RESEARCH IN BUSINESS AND SOCIAL SCIENCES Vol. 9, No. 2, Feb, 2019, E-ISSN: $2222-6990$ ๑ 2019 HRMARS

Sample (adjusted): 2000Q4 2017Q4

Included observations: 69 after adjustments

$\mathrm{D}(\mathrm{GDP})=\mathrm{C}(1) *(\mathrm{GDP}(-1)+0.104451190628 * \mathrm{BCl}(-1)-$

$0.102967429296 * \mathrm{BCCR}(-1)+0.198614928588 * \mathrm{TBC}(-1)-$

$1.08752127527 * \mathrm{BCT}(-1)-1.35247904331)+\mathrm{C}(2) * \mathrm{D}(\mathrm{GDP}(-$

1))

$+\mathrm{C}(3) * \mathrm{D}(\mathrm{GDP}(-2))+\mathrm{C}(4) * \mathrm{D}(\mathrm{BCl}(-1))+\mathrm{C}(5)$

$* \mathrm{D}(\mathrm{BCl}(-2))+\mathrm{C}(6) * \mathrm{D}(\mathrm{BCCR}(-1))+\mathrm{C}(7) * \mathrm{D}(\mathrm{BCCR}(-2))+\mathrm{C}(8)$

$* \mathrm{D}(\mathrm{TBC}(-1))+\mathrm{C}(9) * \mathrm{D}(\mathrm{TBC}(-2))+\mathrm{C}(10) * \mathrm{D}(\mathrm{TBC}(-1))+\mathrm{C}(11)$

$* \mathrm{D}(\mathrm{TBC}(-2))+\mathrm{C}(12)$

\begin{tabular}{|c|c|c|c|c|}
\hline & $\begin{array}{r}\text { Coefficien } \\
\mathrm{t}\end{array}$ & Std. Error & t-Statistic & Prob. \\
\hline$C(1)$ & -0.076556 & 0.026684 & -2.868977 & 0.0058 \\
\hline$C(2)$ & 0.671220 & 0.125127 & 5.364297 & 0.0000 \\
\hline$C(3)$ & 0.283962 & 0.150193 & 1.890645 & 0.0638 \\
\hline$C(4)$ & 0.005536 & 0.012709 & 0.435622 & 0.6648 \\
\hline$C(5)$ & 0.004363 & 0.010175 & 0.428764 & 0.6697 \\
\hline$C(6)$ & 0.016801 & 0.052294 & 0.321281 & 0.7492 \\
\hline$C(7)$ & 0.001109 & 0.049175 & 0.022552 & 0.9821 \\
\hline$C(8)$ & 0.084781 & 0.105812 & 0.801245 & 0.4263 \\
\hline$C(9)$ & -0.020661 & 0.100627 & -0.205319 & 0.8381 \\
\hline$C(10)$ & -0.053825 & 0.026304 & -2.046248 & 0.0454 \\
\hline$C(11)$ & -0.023036 & 0.026137 & -0.881379 & 0.3818 \\
\hline$C(12)$ & 0.000211 & 0.001264 & 0.167333 & 0.8677 \\
\hline R-squared & 0.714422 & \multicolumn{3}{|c|}{ Mean dependent var 0.008445} \\
\hline Adjusted R-squared & 0.659310 & \multicolumn{2}{|c|}{ S.D. dependent var } & 0.008496 \\
\hline S.E. of regression & 0.004959 & \multicolumn{2}{|c|}{ Akaike info criterion } & 7.618354 \\
\hline Sum squared resid & 0.001402 & \multicolumn{2}{|c|}{$\begin{array}{l}\text { Schwarz criterion } \\
\text { Hannan-Quinn }\end{array}$} & 7.229813 \\
\hline Log likelihood & \multicolumn{3}{|c|}{274.8332 criter. } & 7.464207 \\
\hline F-statistic & 12.96317 & \multirow{2}{*}{\multicolumn{2}{|c|}{ Durbin-Watson stat }} & 2.064403 \\
\hline Prob(F-statistic) & 0.000000 & & & \\
\hline
\end{tabular}

Source: Computed by using E-views 8.

From the previous table, we note that error correction has a negative sign and a significant value at $5 \%$, thus confirming the long-term equilibrium relationship between economic growth and bank credit. Thus model is able to correct the time error, Which indicate that the economic growth 
INTERNATIONAL JOURNAL OF ACADEMIC RESEARCH IN BUSINESS AND SOCIAL SCIENCES

Vol. 9, No. 2, Feb, 2019, E-ISSN: $2222-6990$ ๑ 2019 HRMARS

function takes about 13.1 years to return to their equilibrium value after any shock due to the change in the behavior of the variables explained.

\section{Conclusion and Recommendation}

This paper was objected to study the role of bank credit on economic outgrowth in Kuwait, using standard analysis method and a number of tests were applied through quarterly reports for time serirs (2000 - 2017), The results of the "Johansen cointegration tests" showed existence of two long-term equilibrium relation between the study variables according to the (Trace statistic test) and the existence of one equilibrium relation between the variables according to the (Max-Eigen test). The results of the assessment was also showed that there was a small correlation between the variables of this study In the short term.

The results of the Granger causality showed a causal relation between the total bank loans and credit granted to the construction and real estate sector as well as between bank credit granted at trade sector and loans granted at industrial sector, The results also appear a one-way causal relation from GDP to bank credit granted at the construction and real estate sector, from GDP to bank credit at the industrial sector, from bank credit granted at the construction and real estate sector to bank credit at the industrial sector, from bank credit at the sector of trade to bank credit granted at the construction and real estate sector and from bank credit at the sector of trade to the industrial sector.

From this study, we concluded that the bank credit provided by banks to various economic sectors has a little positive impact on Kuwaiti economic activity, Because of the trend of bank credit for individuals rather than directing them to production companies. Which in turn leads to increased consumption, However, this increase does not result in increased productivity due to the lack of local production expansion and reliance on imports, Thus, that the bank loans granted do not affect economic growth effectively.

So we recommend that the Central Bank of Kuwait should review the controls on credit facilities by strengthening its monetary policy in a way that leads to the organization of the granting of credit and the channeling of banking loans to productive sectors, We also recommend the Kuwaiti government to support the production sector and to give reassurance to banks of fear about the failure of private companies, which will lead to encourages them to increase the volume of bank credit directed to productive projects, This would increase investment and growth in the Kuwait economy.

\section{References}

Aimer, M., Lusta, A., \& Abomahdi, M. (2017). The Impact of Electronic Commerce on Libya's Economic Growth, Clear International Journal of Research in Commerce \& Management, 8(4) 62-67 .

Abd al-Razzaq, K., \& Al-Jubouri, A. (2012 ). A Comparative Study in the Methods of Estimating the

Regression of Joint Integration, Iraqi Journal of Economic Sciences, 10, (33) 151-172 .

Amiri, A. (2003). Impact of bank credit on growth Economist in Yemen (1999-2000). Unpublished

Master Thesis, Faculty of Economics, Yarmouk University, Irbid, Jordan.

Alfara, M., (2012). The role of the banking sector in financing the Palestinian Economic Development (1995 - 2011). Master thesis, Islamic University, Gaza, Palestine. 
AlHabib, F. (2000). Principles of Macroeconomics. (4 ${ }^{\text {th }}$ Ed.). King Fahad National Library.(pp.63-65). Riyadh, Saudi Arabia .

Alkhazaleh, A. (2017). Does banking sector performance promote economic growth? Case study of Jordanian commercial banks, Problems and Perspectives in Management, 15 (2),55-64 .

Alqadeer, K. (2004). The Effect of Financial Development on Economic Growth in Saudi Arabia, Journal of King Abdulaziz University:Economics and Management, 18 (1) 3-23.

Alsayed, A., \& Almonem, A. (1984). Economics of money and banks, University of Mosul Press, part 1, 42-49.

Belinga, T., Zhoun, J., Doumbe, D., Gahe, Z., \& Koffi, Y. (2016). Causality Relationship between Bank Credit and Economic Growth: Evidence from a Time Series Analysis on a Vector Error Correction Model in Cameroon, Procedia - Social and Behavioral Sciences 235, 664- 671.

Brooks, C. (2008). Introductory Econometrics for Finance. $\left(2^{\text {nd }}\right.$ ed.). Cambridge University, (pp.350351), New York.

Burzynska, K. (2009). Financial Development and Economic Growth: The Case of Chinese Banking Sector, Master Thesis, Lund University School of Economics and Management Department of Economics.

Buiguta, S. (2011). Fast-Track East African Community Monetary Union Convergence Evidence from A Cointegration Analysis, International Journal of Economics and Finance, 3(1), 255-261 .

Caporale, G,. Rault, C., Diana, A., \& Sove, R. (2009), Financial Development and Economic Growth: Evidence from Ten New EU Members, Discussion Paper of DIW Berlin, 9(37), 1-39.

Central Bank of Kuwait, Annual reports for years 2000-2017. http://www.cbk.gov.kw/en/statisticsand-publication/statistical-releases/quarterly.jsp .

Christophe, N. (2016). Financial intermediation and Economic growth in Nigeria (1970-2013), International Journal of Advanced Education and Research, 1 (12),1-14 .

Copelman, M. (2000). Financial Structure and Economic Activity in Mexico, Center of Analysis and Economic Research, ITAM, 1-49, Retrieved from http://citeseerx.ist.psu.edu .

Ceçe, M. (2012). The effects of bank credits on economic growth in Turkey, Master Thesis, Social Sciences institute, Istanbul university .

Damondar, N., \& Gujarati, (2004). Basic Econometrics. (4 ${ }^{\text {th }}$ ed.). (pp. 814-818). New York, McGrawHill .

Emmanuel, O., Abiola, A., \& Anthony, U. (2015). Impact of private sector credit on economic growth in Nigeria , The Central Bank of Nigeria, Abuja, 6 (2), 81-101 .

John, A., \& Kimberly, F. (2015). The Impact of Credit Line Drawdowns on Investment Evidence from the Financial Crisis, Retrieved from https://ssrn.com/abstract=2813936 .

Johansen, S. \& Juselius, K. (1990). Maximum Likelihood Estimation and Inference on Cointegrationwith Application to the Demand for Money, Oxford Bulletin of Economics and Statistics, 52, 169210.

Kamin, S. \& Rogers, J. (2000). Output and the Real Exchange Rate in Developing Countries: An Application to Mexico, Journal of Development Economics, 61 (1), 85-109.

Suna, K. (2015). Impact of Bank Credits on Economic Growth and Inflation, Journal of Applied Finance \& Banking, 5 (1), 57-69. 
INTERNATIONAL JOURNAL OF ACADEMIC RESEARCH IN BUSINESS AND SOCIAL SCIENCES

Vol. 9, No. 2, Feb, 2019, E-ISSN: $2222-6990$ ๑ 2019 HRMARS

Schumpeter, J. (1911). Theorie der wirtschaftlichen Entwicklung. Translated by Trans. Markus C. Becker and Thorbjorn Knudsen. American Journal of Economics and Sociology, 61(2) .

World Bank. (2012). Retireved from

http://documents.worldbank.org/curated/en/492221468136792185. 